\title{
Contracampo
}

\section{O livro como produto midiático e os estudos de recepção ${ }^{1}$}

\section{Book as a product and media reception studies}

Isabel Travancas

isabeltravancas@yahoo.com.br

Professora do Departamento de Antropologia Cultura do IFCS/UFRJ, mestre em Antropologia Social pelo Museu Nacional-UFRJ e doutora em Literatura Comparada pela UERJ.

${ }^{1}$ Uma versão deste texto foi apresentada no XXI Encontro Anual da Compós, na UFJF, em junho de 2012.

\section{PPGCOM}

Ao citar este artigo, utilize a seguinte referência bibliográfica

TRAVANCAS, Isabel. O livro como produto midiático $e$ os estudos de recepção. In: Revista Contracampo, v. 26, n. 1, ed. abril, ano 2013. Niterói: Contracampo, 2013. Págs: 87 - 105.

Enviado em: 16 de ago. de 2012

Aceito em: 22 de dez. de 2012

\section{Edição 26/2013}

Contracampo

e-ISSN 2238-2577

Niterói (RJ), v. 26, n. 1, abril/2013.

www.uff.br/contracampo

A Revista Contracampo é uma revista eletrônica do Programa de Pós-Graduação em Comunicação da Universidade Federal Fluminense e tem como objetivo contribuir para a reflexão crítica em torno do campo midiático, atuando como espaço de circulação da pesquisa e do pensamento acadêmico. 


\section{Resumo}

Este artigo procura discutir o lugar do livro no contexto midiático e as perspectivas de compreensão dos textos literários a partir de diferentes estudos de recepção. Partindo da Escola de Constança e de sua estética da recepção, levando em conta a visão de Iser sobre o papel do leitor e a discussão realizada por Eco sobre o leitor modelo, chega-se às pesquisas sobre recepção de produtos midiáticos e à escassez de trabalhos que investiguem o universo do livro e da leitura na sociedade brasileira. Este texto é parte inicial de uma pesquisa mais ampla, de base antropológica, sobre a experiência da leitura entre adolescentes da Zona Sul e da periferia da cidade do Rio de Janeiro no início do século XXI.

Palavras-chave: livro; recepção; adolescentes.

\section{Abstract}

The aim of this paper is to discuss the place of the book within the media context and perspectives for understanding literary texts based on different reception studies. The School of Constance and its reception aesthetics were the starting points, and Iser's view on the reader's role as well as Eco's discussion on the model reader were taken into consideration. This led to research on the reception of media products and the realization that there are few studies investigating the world of books and reading in the Brazilian society. This text is the initial part of broader research anchored on anthropology about the reading experience of adolescents of the South Zone and the outskirts of the city of Rio de Janeiro in the early 21st century. Keywords: book; reception; adolescents. 
$\mathrm{V}$ enho me questionando sobre a leitura no Brasil, a formação do leitor e o papel da escola nesse contexto. Decidi então investigar os adolescentes, num país de jovens, mas conhecido por não ser leitor. Gostaria de averiguar como se dá esse contato com o livro na adolescência, se esses adolescentes leem, como leem e quais são as suas interpretações do que leem. Pensando um pouco nos termos de Martín-Barbero (2001), que fala em modos de ver para pensar a televisão, pretendo discutir os modos de ler.

Portanto, o livro é o eixo central deste trabalho e coloca, a meu ver, muitas questões num momento de predominância de mídias digitais e audiovisuais. Ao mesmo tempo, oferece uma gama muito ampla de estilos e gêneros. Sabe-se que o romance é o gênero privilegiado dos leitores e do mercado editorial brasileiro e internacional. $\mathrm{O}$ gênero mais lido e mais vendido. Estima-se que, apesar de o Brasil não ter uma tradição de leitura entre a sua população, nem o hábito disseminado de forma abrangente, os livros para jovens têm vendido milhões de exemplares com títulos como Harry Potter e Crepúsculo, ou os livros de Thalita Rebouças, para citar uma autora brasileira.

Entendo o livro como um suporte midiático que serve de base para diversas estratégias através das quais ele migra para outras plataformas digitais nas quais sua narrativa ganha espaço e passa a circular mais velozmente em territórios longínquos.

Segundo dados da pesquisa Retratos da Leitura no Brasil, realizada em 2007 pelo Instituto Pró-Livro (AMORIM, 2008, p. 27), existem no país 95 milhões de leitores e 77 milhões de não leitores e a média de livros lidos por habitante, ao longo de um ano, está em torno de 1,2 (sem contar com os escolares) 4,7 livros, (incluindo os escolares). 1,2 ou 4,7 livros? A frase está confusa. A casa é o lugar predileto para a leitura para 57\%, enquanto $4 \%$ lê em algum meio de transporte e 1\% em lan house. Sabe-se que, quanto maior a escolaridade, mais tempo é dedicado à leitura dos livros. Por outro lado, ficou claro através da pesquisa que grande parte do universo investigado abandona o livro ao sair da escola. Esta não ajudou a criar leitores e não propiciou um vínculo entre livro e leitor que independa da obrigatoriedade e do ensino. A leitura não se tornou um hábito nem um prazer para uma grande parcela da população brasileira, segundo os dados deste levantamento. 
A pesquisa foi realizada em todo o país: em 311 cidades foram aplicados 5.012 questionários. E, diferentemente da enquete anterior, incluiu a parcela da população com idade de 5 a 13 anos que tinha ficado de fora. Foram considerados leitores aqueles que, no momento da entrevista, afirmaram ter lido pelo menos um livro nos três meses anteriores. Foram considerados não leitores os que declararam não ter lido nenhum livro no mesmo período, ainda que tivessem lido ou mesmo folheado um nos últimos seis meses. Certamente esses critérios podem e devem ser discutidos, mas no âmbito deste artigo, busco discutir o lugar do livro e de sua recepção no Brasil tendo esses dados como parâmetros. Dentro desse universo não leitor, a maior parcela está entre os adultos com idade a partir de 30 anos. E este número diminui de acordo com o nível de escolarização, renda familiar e classe social.

Muito se fala sobre o valor simbólico e social do livro e da leitura e discutirei esse ponto mais adiante. Nesse sentido, um dado presente nos questionários me pareceu relevante para entender a dimensão, ou melhor, a pequena dimensão simbólica do livro em nosso país: 85\% dos não leitores nunca foram presenteados com livros na infância. Ou seja, o livro não é considerado um presente, algo que uma criança deve ganhar, mereça ou vá gostar. É inevitável lembrar do texto clássico do pensador francês Marcel Mauss (1974) Ensaio sobre a dádiva, onde ele analisa o significado do dar, receber e retribuir como elementos fundadores da vida social. A antropóloga Maria Claudia Coelho (2006), em um estudo sobre a dádiva na sociedade brasileira, destaca o quanto os presentes são vistos como "meios de comunicação" e possibilitam dar visibilidade a estados afetivos. E o quanto os afetos se expressam e são lidos por muitos grupos através do valor do presente e de seu significado como “é a sua cara”, “é uma lembrancinha”. Tudo isso me faz pensar na ausência do livro dentro da categoria presente como algo que você dá ao outro e que é expressão do seu afeto por ele. Não leitores certamente não pensarão nele como um presente desejável - isso sem entrarmos no mérito da inexistência de livrarias e pontos de venda de livros em vários municípios brasileiros.

Sabemos que a indústria cultural, assim cunhada por Adorno e Horkheimer (1990), continua em amplo processo de transformação. Não só novos produtos são criados, com novas linguagens, como a percepção e utilização dos antigos se renovam e se alteram. O livro é um exemplo dessas transformações. Se, ao longo de sua história, 
ele se modificou muito até chegar à brochura tal como conhecemos hoje, isso não quer dizer que o processo esteja encerrado. Novos suportes e novas tecnologias têm surgido nas últimas décadas, possibilitando novas práticas de leitura. O kindle é, certamente, um exemplo.

Ouso afirmar que o livro não tem sido um objeto privilegiado de pesquisa nos Programas de Pós-Graduação em Comunicação, não sendo muitas vezes entendido como um produto da indústria cultural, mas visto como um tema relacionado aos estudos literários ou históricos. E se são poucos os estudos sobre ele, mais escassos ainda são os trabalhos sobre recepção de livros. A coletânea Meios e audiências (2008), organizada pela pesquisadora Nilda Jacks, apresenta uma investigação de teses e dissertações na área de comunicação no país sobre audiência, principalmente estudos de recepção, e não cita nenhuma pesquisa nesta área.

\section{$O$ receptor na literatura}

Literatura é um termo complexo e fugidio. Para Domício Proença (2007), a marca do texto literário é a sua plurissignificação. Ele é polissêmico e, portanto, pode apresentar muitos significados. A linguagem literária é conotativa e tem enorme liberdade em relação às normas, porque a criação estética autoriza qualquer transgressão: sua característica é a invenção. Mas não se pode esquecer que ela também está ligada à ideia de imitação, de mímesis.

O professor de literatura brasileira e escritor Gustavo Bernardo (1999), em seu artigo sobre o conceito de literatura, discorre sobre sua complexidade, apontando para as pistas deixadas por outros escritores e teóricos. Bernardo cita o poeta Fernando Pessoa, quando este fala em mímese e catarse. O primeiro conceito controverso na área de teoria literária aponta para a perspectiva ficcional. Já a catarse pode ser entendida como uma espécie de purgação, que permite a identificação com os sofrimentos do personagem. Essa capacidade de produzir catarse está certamente entre os importantes recursos dos livros denominados best sellers e em especial os livros para o público juvenil. É fundamental a identificação com o “mocinho” ou com a “mocinha”, seja ele bruxo ou vampiro. 
Ao nos determos no texto literário, inevitavelmente iremos chegar ao seu destino: o leitor. Uma das primeiras correntes de pensamento a se preocupar de forma mais sistemática com o receptor foi a chamada Estética da recepção, da qual Hans Robert Jauss é um de seus mentores. Jauss nasceu na Alemanha nos anos 1920 e fez parte da Escola de Konstanz, na qual um grupo de intelectuais ligados à área de estética e literatura se reunia.

A ideia de experiência estética como atividade produtora, receptiva e comunicativa foi um ponto importante juntamente com a percepção do prazer estético como orientação fundamentadora, ao mesmo tempo em que não é entendida como um privilégio dos especialistas. Sugestão: reestruturar a frase acima, deixando-a mais clara.

Para Jauss (2001) há uma diferença entre o ato de recepção e o de interpretação. E é a hermenêutica literária, ou seja, a teoria da interpretação de vários sinais como símbolos de uma cultura que irá estabelecer a distinção entre dois modos de recepção. O primeiro diz respeito a um processo em que se concretizam o efeito e o significado do texto para o leitor contemporâneo. O segundo reconstrói o processo histórico pelo qual o texto é sempre recebido e interpretado diferentemente por leitores diversos. Sua grande preocupação é com a construção de uma teoria que dê conta do processo dinâmico de produção e recepção e da dinâmica entre autor, obra e público.

Neste sentido, a recepção irá colocar a comunicação entre os dois lados da relação: texto e leitor. Entenderá esse processo em que o efeito será o momento condicionado pelo texto e a recepção como o momento condicionado pelo destinatário. A noção de um horizonte de expectativa, tanto interno ao texto como social, será um conceito importante desta corrente.

Wolfgang Iser, outro pensador que faz parte do universo de estudiosos da literatura e de sua recepção estética, irá colocar ao lado da teoria da recepção uma teoria do efeito estético. A seu ver, esta teoria “conduz, a partir dos processos de transformação, à constituição do sentido pelo leitor e que descreve a ficção como uma estrutura de comunicação" (ISER, 1979, p. 53). A literatura é, portanto, comunicação e sua recepção, assim como a de outras artes, não significa um consumo passivo, mas uma atividade estética que aguarda uma aprovação ou recusa. Isso porque a relação com o texto é sempre ativa e receptiva: um leitor não pode concretizar a significação, o 
sentido potencial de uma obra, se ele não insere a sua pré-compreensão do mundo e da vida dentro do quadro de referências literárias do texto.

Nesta espécie de passeio pela literatura e sua recepção, chegamos ao "bosque” do escritor e semiólogo Umberto Eco (1994). Ele usa o bosque como metáfora do texto narrativo e trabalha com a ideia de escolha do leitor diante do texto ficcional. Este leitor pode ser classificado em categorias. O leitor modelo, por exemplo, será uma espécie de tipo ideal que o texto não só prevê como colaborador, mas procura criar. Não é o leitor empírico, que entendo como qualquer um que lê o texto. Já o autor como entidade empírica irá escrever a história e decidirá que leitor-modelo lhe compete construir. Há também o autor modelo, que funcionará como uma voz que fala ao leitor afetuosamente, que quer tê-lo ao seu lado. Eco vai lançar mão da perspectiva de Iser e de seu leitor implícito, ao lembrar que a estrutura textual prevê a presença de um receptor. O leitor modelo de Eco se parece com o leitor implícito de Iser. E se ele for modelo-implícito fará o texto revelar sua multiplicidade potencial de associações, que são produto da mente do leitor sobre o material bruto do texto. Nesse processo, é formulado algo que não está no texto, mas representa a sua “intenção”. Fica evidente que, para Eco, “o leitor é o ingrediente fundamental” (ECO, 1994, p. 7) da própria história.

\section{Sobre a leitura e o leitor}

Sabemos que a leitura, como bem afirma Roger Chartier, é "sempre apropriação, invenção e produção de significados” (CHARTIER, 1998, p. 77). É, portanto, uma prática cultural que irá se diferenciar no tempo, no espaço e nos grupos sociais. Não se lê sempre da mesma forma. Basta lembrarmos da leitura em voz alta realizada na Idade Média, quando apenas uns poucos religiosos dominavam o processo da escrita. Hoje estamos habituados a uma leitura individual, silenciosa e extensiva. Lemos vários textos ao mesmo tempo e a linguagem virtual veio redimensionar esse aspecto com a ideia de hipertexto. E se a leitura no século XII e XIII era um gesto de escuta, hoje ela exige o sentido da visão para se realizar, ainda que os audiobooks estejam reconfigurando esse cenário dos sentidos também.

Para o historiador da leitura Alberto Manguel (1997), ler vem antes de escrever. 
É o leitor que lê o sentido, é o leitor que confere a um objeto, lugar, acontecimento uma certa legibilidade possível. É o leitor que deve atribuir significado a um sistema de signos e depois decifrá-lo. E por isso, a seu ver ler não é um processo automático de captura de um texto mas um processo desconcertante, labiríntico, comum e contudo pessoal(MANGUEL, 1997, p. 19).

“A leitura não é simplesmente uma habilidade e sim uma maneira de fazer sentido, que deve variar de cultura para cultura”, afirma o historiador norte-americano Robert Darnton (DARNTON, 1990, p. 159). Para o estudioso, as razões de ser da leitura foram as mais variadas e continuam sendo. A leitura serve "para salvar almas, para refinar maneiras, consertar máquinas, seduzir namoradas, informar-se ou simplesmente entreter” (DARNTON, 1990, p. 155). Conhecer e entender as práticas leitoras de uma sociedade ou época pode ser uma importante forma de acesso à sua história e à sua cultura. Um pouco como dizes o que lês e eu te direi quem és. Darnton fez pesquisas minuciosas na França de antes da Revolução Francesa, tendo como fontes primárias catálogos de empréstimo de bibliotecas e listagens de livreiros.

Martín-Barbero, ao pensar a leitura como prática cultural na contemporaneidade, irá afirmar que:

estamos diante de uma mudança nos protocolos e processos de leitura, que não significa, nem pode significar a simples substituição de um modo de ler por outro, senão a articulação complexa de um e outro, da leitura de textos e da leitura de hipertextos, da dupla inserção de uns em outros, com tudo que isso implica de continuidade e rupturas, de reconfiguração da leitura como conjunto de modos muito diversos de navegar pelos textos (MARTÍN-BARBERO, 2001, p. 62).

\section{Estudos de recepção no Brasil em dois campos: a comunicação e antropologia}

Para Jacks sugestão: ampliar a frase antes de citar, já que se trata do início de um subtópico.

Caso o alinhamento não fique ajustado, reescrever o trecho abaixo, de modo a alinhá-lo.

O processo de recepção é visto como algo que não se dá apenas no momento de interação com os meios de comunicação, mas começa bem antes e termina bem depois, fundindo-se com as práticas cotidianas dos receptores, ação onde ganha sentido ou não, através da 
negociação com os significados propostos pela família, escola, religião, partido político, empresa, etc. (JACKS, 1993, p. 48-9).

O que me parece fundamental nesta afirmação é pensar a complexidade da recepção que envolve um capital cultural e simbólico nos termos de Bourdieu (1964), que é anterior ao ato receptivo e contribui para sua significação.

A tradição de estudos de recepção no Brasil está extremamente ligada à televisão. A análise deste campo de pesquisa no país, na segunda metade do século XX, realizada pelas pesquisadoras Ana Carolina Escosteguy e Nilda Jacks (ESCOSTEGUY \& JACKS, 2005, p. 67-84), faz um balanço da problemática da recepção midiática na área acadêmica. De um lado, tem-se a pesquisa de audiência sobre televisão, que é mais quantitativa e ligada ao mercado. De outro, as pesquisas mais qualitativas, também empíricas, mas com o foco nos receptores. No âmbito internacional, a expressão estudos de recepção está relacionada às pesquisas sobre os efeitos, as influências e relações dos sujeitos com os meios dentro dos seus contextos culturais. Não é à toa que MartínBarbero (MARTÍN-BARBERO, 2001, p. 39) fala de um “lugar novo” a partir de onde as pesquisas de comunicação devem ser repensadas.

A partir dos anos 1970, começaram a surgir trabalhos que problematizaram o receptor e tinham-no como seu foco central. Trabalhos produzidos não apenas dentro dos Programas de Pós-Graduação em Comunicação, mas nas Ciências Sociais, como é o caso da pesquisa de Sergio Miceli, A noite da madrinha (1972); O paraíso via Embratel (1977), de Luiz Augusto Milanesi; Muito além do Jardim Botânico (1984), de Carlos Eduardo Lins e Silva e a etnografia de audiência de Ondina Leal: Leitura social da novela das oito (1986). Gostaria de destacar a pesquisa de Leal por ser um trabalho pioneiro, uma vez que a autora é antropóloga e o produziu como dissertação de mestrado dentro do Programa de Pós-Graduação em Antropologia Social da UFRGS.

Para Leal, o eixo central desse tipo de investigação - etnografia de audiência está na noção de cultura como um sistema de significados. A diferença do seu trabalho para o de Lins e Silva, citado acima, está no fato de que naquele há uma limitação, já que as pessoas não estão em seu local de moradia, não sendo resgatado o cotidiano da recepção. "Não temos o como as pessoas recebem determinada mensagem, mas uma opinião a respeito da mensagem” (LEAL, 2002, p. 117), destaca a antropóloga. Para ela, é fundamental perceber como o receptor assiste, respira e interage com o que está vendo. Por isso, afirma fazer uma etnografia de audiência e não de recepção, uma vez 
que o termo audiência remete mais à ideia de coletivo; já recepção dá uma noção de individualização. A seu ver, o momento da recepção na perspectiva antropológica é um evento de fala. O objetivo seria realizar uma etnografia da fala, onde todos os comentários, gestos, intervenções e ausências fazem parte do processo de recepção.

Esta vertente, que procura estabelecer um diálogo estreito entre o campo da comunicação e da antropologia, não só muito me interessa como é o lugar de onde falo e de onde também venho produzindo estudos. Acredito que esta interação entre as duas áreas - comunicação e antropologia -, particularmente no que diz respeito aos estudos de recepção ou etnografias de audiência, pode ser muito fértil. Assim como cresceu substantivamente a produção acadêmica na área de comunicação sobre recepção, também vem aumentando o número de trabalhos antropológicos que têm os meios de comunicação de massa, seus produtores e receptores como tema.

Embora a antropóloga Debra Spitulnik (SPITULNIK, 1993, p. 293), ao abordar a interseção entre antropologia e comunicação, afirme que ainda não é possível falarmos em uma "antropologia dos meios de comunicação de massa", ela mesmo destaca que na última década do século XX cresceu o interesse em estudá-los. Segundo Spitulnik, já há inúmeras maneiras de se abordar os meios de comunicação de massa: como instituições, lugares de trabalho, práticas comunicativas, produtos culturais, atividades sociais, formas estéticas e desenvolvimentos históricos.

\section{Pesquisas sobre livro, leitura e leitor no Brasil}

Como já salientei antes, são escassas no país as pesquisas sobre livro e leitura no âmbito da comunicação. O professor Muniz Sodré (1988) publicou, nos anos 1980, uma reflexão sobre os best sellers, em que analisava-os como exemplares da categoria "literatura de massa”. Ele tomou como referência a obra Os mistérios de Paris, de Eugéne Sue, datada de 1842. Esse folhetim foi publicado no rodapé dos jornais da época de grande tiragem e era considerado uma espécie de "literatura industrial”, não legitimada pelas instituições escolares e acadêmicas e sim pelo mercado. Sodré conclui afirmando que, além de o best seller ser visto como um produto de massa, resultado do processo capitalista de mercantilização, ele pode ajudar a entender, através de sua narrativa, um pouco da cultura ocidental e de como populações pouco letradas se 
relacionam com a leitura. Isso se nos despirmos dos preconceitos em relação ao seu caráter reacionário e de entretenimento.

A pesquisadora Sandra Reimão (1996) tem vários trabalhos publicados sobre mercado editorial, best sellers e vem discutindo e estimulando o estudo deste campo tanto dentro da universidade como no âmbito de congressos da área, a exemplo da Intercom. Em seu livro sobre a cena editorial brasileira, faz uma análise dos best sellers e da trajetória do mercado brasileiro dos anos 1960 aos 1990.

O livro Impresso no Brasil (2010), organizado pelo professor Aníbal Bragança e pela professora Márcia Abreu, veio suprir uma lacuna de trabalhos científicos sobre o tema, em particular a história do livro no Brasil. Até praticamente uma década atrás, o clássico O livro no Brasil: sua história, do estudioso inglês Laurence Hallewell (1985), reinava solene como a única grande referência sobre a história do livro no país.

A série Harry Potter foi estudada pela professora Sílvia Borelli (2010) com alguma intensidade. Seu artigo Campo editorial e mercado: a série Harry Potter procura analisar o campo editorial e literário no contexto nacional e internacional e entender o lugar privilegiado da série do bruxo inglês. A partir de uma leitura tendo como base os conceitos do sociólogo francês Pierre Bourdieu, Borelli traça um retrato do processo de mundialização da obra de J. K Rowling e suas estratégias mercadológicas. Para a autora, ficou claro que os livros da série "retomam mitos fundadores e colaboram para a formação de leitores modernos” (BORELLI, 2010, p. 397).

Além dos textos citados, na última década começaram a ser produzidas algumas pesquisas sobre o tema. São exemplos disso os trabalhos de Gilberto Cardoso (2002) Comunicação e recepção; de Richard Romancini (2002) Apropriações de Paulo Coelho por usuários de uma biblioteca pública; de Elza Garcez (2001) Leitura, escola, leitor: uma trama plural e de Montgomery de Vasconcelos (2002) Recepção e transgressão: o público de Augusto dos Anjos.

Dentro da perspectiva da recepção, são mais raros os estudos sobre o livro e o leitor. O trabalho da pesquisadora Ecléa Bosi (2009) é certamente um marco nesta área. Trata-se de um estudo realizado com mulheres operárias na década de 1970 sobre a leitura. Foram entrevistadas mais de 50 mulheres de 19 a 35 anos, sendo que a maioria tinha curso ginasial completo. A leitura mais presente nos discursos é de revista e de fotonovela, um gênero muito presente nas bancas de jornais naquela década. Em relação 
aos livros, muitas não lembram o que leram. E a Bíblia é muito citada, da mesma forma em que apareceu na pesquisa Retratos da leitura no Brasil (2008) com grande destaque. O que fica evidente através dos depoimentos é o quanto o livro e o hábito da leitura não fazem parte de suas vidas. Excesso de trabalho, cansaço, falta de tempo são alguns dos argumentos. Muitas lembram das leituras da época da escola, dado que também aparece na pesquisa do Instituto Pró-Livro tantos anos depois.

A pesquisa desenvolvida pelas professoras do Ceará, Roberta Manuela Andrade e Erotilde Silva (2011) aborda as práticas de leitura dos livros do coração por um grupo de mulheres em Fortaleza. Essa comunidade interpretativa, real e virtual, de diferentes gerações e posições sociais é leitora de romances sentimentais e frequentadora de bancas de revistas do centro da cidade.

Andrade e Silva perceberam que essas mulheres consomem livros em espaços privados e públicos, de forma isolada ou compartilhada, em momentos específicos ou aleatoriamente. Compram em redes oficiais e também trocam e negociam romances de coleções anteriores. A pesquisa foi feita em três espaços sociais distintos: bancas de jornais, sebos, na comunidade virtual de leitoras de romances no Orkut - Adoro romances em Fortaleza - e em um grupo que se reúne periodicamente no bairro Granja Portugal. São 3 ou 4 espaços?

Ficou evidente com a pesquisa que:

o prazer que a leitura dos romances sentimentais aloca não está somente na fruição do texto, mas, se encontra no fato de ser um prazer compartilhado. As leitoras abordadas afirmam que um dos maiores prazeres oriundos da leitura é a sociabilidade que tal prática engendra. Todas as nossas leitoras afirmam 'conversar com pessoas' sobre os romances, mas o fazem com diferentes interlocutores: amigas, reais e virtuais e parentes. (...) Assim, ler um livro é mais do que interpretar/incorporar os significados manifestos ou latentes do texto, é uma prática social cujos desdobramentos ainda estão muito longe de serem minimamente compreendidos pela academia (ANDRADE E SILVA, 2011, p. 14).

Uma etnografia de audiência em andamento: os adolescentes e a leitura no Rio de Janeiro 
Meu objetivo com esta pesquisa, em fase inicial, é analisar a relação de um grupo específico - adolescentes do ensino médio do Rio de Janeiro - com a leitura e os livros, em uma primeira etapa e, em seguida, investigar como interagem com os produtos derivados de alguns dos livros mais vendidos, como Harry Potter e Crepúsculo, assim como os filmes, blogs e fóruns de discussão na internet sobre o tema.

Para isso, pretendo selecionar adolescentes que estejam matriculados e cursando escolas particulares da Zona Sul e escolas públicas da Zona Norte ou periferia da cidade do Rio de Janeiro, procurando formar dois subgrupos distintos em termos de origem e classe social. Meu intuito é analisar o discurso dos estudantes moradores de subúrbios cariocas, pertencentes às camadas médias baixas ou camadas populares, e também jovens residentes na Zona Sul do Rio, mais próximos da elite econômica e intelectual, mas também membros do universo de camadas médias urbanas. É importante salientar que entendo a definição de camadas médias como algo mais abrangente e complexo do que classe social, e considero ser possível encontrar semelhanças e parâmetros entre os indivíduos deste grupo.

Dentro deste universo mais amplo de camadas médias e populares, decidi investigar adolescentes entre 11 e 17 anos, levando em conta a afirmação de Pierre Bourdieu (BOURDIEU, 1983, p. 112 e 113) de que as divisões entre as idades são arbitrárias e que a juventude, assim como a velhice, não é dada, mas construída socialmente na luta entre velhos e jovens. Será necessário pensarmos não em juventude, mas em juventudes, não em adolescência, mas em adolescências, e os estudantes poderiam ser entendidos como um segmento desta categoria mais abrangente.

A definição de estudante denota também uma característica muito associada ao jovem, que é estar num lugar transitório, em uma situação intermediária: nem criança nem adulto. O estudante do ensino médio não é criança, já se afasta da infância e começa a pensar em uma escolha profissional. H. colocar primeiro nome por extenso Abramo, em seu trabalho sobre punks e darks, afirma que "a condição juvenil é por excelência a condição estudantil, como um setor particular que pode permanecer de fora do processo produtivo e do sistema de valores constituídos” (ABRAMO, 1994, p. 20).

Escolhi fazer esta investigação centrada em dois grupos distintos por acreditar que a perspectiva comparativa será rica para entender e nuançar as relações com o livro e outras mídias em contextos socioculturais diversos. A permanência na escola nos dois 
grupos já é um fator importante, na medida em que a evasão escolar cresce no Brasil no ensino médio, principalmente no ensino público. Muitos jovens querem e precisam trabalhar e são obrigados a priorizar seu sustento e não seu aprendizado.

Por outro lado, a adolescência como fase de transição dentro de um ciclo mais amplo de mudanças, que é a juventude, coloca muitas questões. Trata-se de um período de descobertas: sexuais, intelectuais, afetivas, profissionais. O psicanalista Contardo Calligaris, em seu livro Adolescência, afirma que "em outras culturas o equivalente da adolescência é um rito de iniciação, eventualmente acompanhado de provas. Por mais duras que possam ser, elas serão sempre mais suportáveis do que a indefinida moratória moderna” (CALLIGARIS, 2000, p. 18). Para ele, a moratória da adolescência nas sociedades ocidentais modernas é consequência das diversas indefinições, como o que é um homem, uma mulher ou um adulto. Calligaris define o adolescente como:

alguém cujos sentimentos e o comportamento são obviamente reativos, de rebeldia a uma moratória injusta; que tem o inexplicável dever de ser feliz, pois vive uma época da vida idealizada por todos; que não sabe quando e como vai poder sair de sua adolescência (CALLIGARIS, 2000, p. 21).

Também pretendo avaliar nesta investigação como se dá a construção de estereótipos que "rondam" os jovens nascidos depois da ditadura militar brasileira momento em que tiveram um papel ativo na luta por transformações da sociedade -, que são vistos muitas vezes como parte de uma geração nascida e criada numa sociedade marcada pela presença da indústria cultural e do consumo. Estes jovens, em muitos aspectos, são considerados alienados, agindo dentro de uma lógica individualista, hedonista e indiferente às questões políticas e aos movimentos sociais. É importante salientar, no entanto, que cada geração de jovens é delimitada por uma conjuntura específica e experiências definidas por esta, e apresentará maneiras próprias de comportamento e ação, assim como um tipo particular de relação com o passado cultural de que é herdeira. Ela quem? precisará, em alguma instância, diferenciar-se de seus modelos, numa luta entre continuidade e ruptura. Avaliar estas ideias em relação ao grupo pesquisado também será enriquecedor para este trabalho.

Outra ideia que direciona este estudo é o fato de o livro poder ser, para alguns jovens deste grupo, não uma fonte de entretenimento, diversão ou prazer, mas algo entediante, chato e extremamente ligado ao ensino e ao dever escolar. É, portanto, foco 
desta pesquisa aprofundar estas percepções do livro, seus significados e vivências. Ao lado desse aspecto, procurarei, através da pesquisa de campo e das entrevistas em profundidade, ampliar a percepção do livro para os universos familiar e social dos adolescentes estudados. Tentarei averiguar se suas famílias são leitoras, se há livros em suas casas e qual a relação que estabelecem com este objeto. Um objeto carregado de significados, negativos e positivos, certamente.

Acho importante também avaliar quais as relações que estes jovens estabelecem entre literatura e cinema, livros e computadores. Sabemos que os grandes grupos econômicos ampliaram seu leque de opções, trazendo conteúdos em diferentes suportes ou plataformas. O caso de Harry Potter é exemplar. Há produtos criados para atuarem simultaneamente em mídias distintas, como o livro, o filme, o jogo de computador e os portais da internet, como destacou Sílvia Borelli (2007). Estamos falando, portanto, do potencial da convergência midiática. Será fundamental descobrir o quanto dessa convergência aparece no discurso dos adolescentes. É o mesmo público que lê o livro, vê o filme, compra o jogo e acessa blogs e discute seu conteúdo em fóruns?

Assim, creio que será necessário também ampliar ao máximo a compreensão do consumo cultural destes adolescentes, assim como suas relações com as novas tecnologias: celulares, iPod, iPod touch, iPhone, entre outras.

Em termos de metodologia, creio que a observação participante, as entrevistas qualitativas e a elaboração da etnografia podem ser elementos preciosos na percepção que os adolescentes aqui selecionados têm do livro, da leitura e das outras mídias. Será possível afirmar que o livro não é referência para os adolescentes? Qual o tipo de contato que estabelecem com esse objeto/produto a partir da escola? Qual a leitura que os estudantes de escolas públicas e particulares fazem dos textos ficcionais? E ainda, qual a relação que esta interpretação tem com seu ethos, seu estilo de vida e perspectiva diante do mundo? Paralelamente, investigarei a relação desses jovens com suas outras formas culturais como audiolivro, filme, jogo eletrônico, blogs, fóruns e outras redes sociais e como se relacionam com essas outras mídias.

\section{Conclusão}


O tema discutido neste trabalho é vastíssimo e minha pesquisa ainda está em fase inicial, trazendo muito mais perguntas do que respostas, uma vez que a etnografia e o trabalho de campo ainda não começaram.

Creio que alguns pontos relevantes ficaram mais claros. O primeiro deles é o número reduzido de pesquisas sobre o universo do livro, da leitura e do leitor dentro do campo da comunicação. Há alguns trabalhos importantes, estudos que são referência, mas esse não é um objeto privilegiado como tema de investigação. Isso, a meu ver, coloca algumas questões interessantes. A primeira delas aponta para o fato de o livro não ser entendido como um produto midiático, nem o mercado editorial ser visto como um nicho importante da indústria cultural. Quando Adorno e Horkheimer (ADORNO \& HORKHEIMER, 1985, p. 118) analisaram a indústria cultural, em seu texto clássico, não se esqueceram do livro e explicitaram sua preocupação com a padronização e a produção em série ao falar da "penetração psicológica do romance”, por exemplo. Em outro texto, Caprichos literários (1991), Adorno faz uma crítica ferrenha ao fato de os livros não terem "aparência de livros” e terem se tornado objetos de consumo, o que, para ele, prejudicaria os livros como artigo intelectual por estarem se apresentando como um produto do mercado.

E se há poucas pesquisas sobre o tema, são mais raros ainda os estudos de recepção ou mesmo etnografias que tenham o leitor como foco. Nesse sentido, o trabalho de Ecléa Bosi, de 1972, é pioneiro: trata-se de um estudo sobre a leitura vivida por operárias em uma fábrica, em São Paulo. Ele coloca em cena questões teóricas importantes em relação à comunicação de massa e suas fronteiras com a cultura dita popular ou operária.

Em termos internacionais, a obra da antropóloga francesa Michèle Petit (2008) Os jovens e a leitura - tem sido fonte de inspiração tanto pela metodologia utilizada pela pesquisadora quanto pela profundidade da sua abordagem e a sensibilidade da sua escuta.

Penso que a recepção de livros coloca novos problemas para este campo do conhecimento. Exige uma reflexão sobre o lugar simbólico do livro no Brasil, sobre a relação do grupo pesquisado com o livro, a leitura e a escrita e sobre a relação dos receptores com o conteúdo das obras lidas. Por outro lado, no caso do universo de 
adolescentes, é fundamental pensar nos desdobramentos dos livros, particularmente os best sellers e as séries em outras mídias, como o cinema e a internet.

\section{Referências}

ABRAMO, H. W. Cenas juvenis. São Paulo: Scritta, 1994.

ADORNO, Theodor \& HORKHEIMER, Max. Dialética do esclarecimento. Rio de Janeiro: Zahar, 1990.

. Notas de literatura. Rio de Janeiro: Tempo Brasileiro, 1991.

AMORIM, Galeno.(org.) Retratos da leitura no Brasil. São Paulo: Imprensa OficialInstituto Pró-Livro, 2008.

ANDRADE, Roberta Manuela \& SILVA, Erotilde. "Quem lê tanto romance? As práticas de leitura dos livros do coração”. In: XXXIV Congresso de Ciências da Comunicação - INTERCOM. Recife, 2011, p. 1-15.

BOSI, Ecléa. Cultura de massa e cultura popular. Petrópolis: Vozes, 2009.

BOURDIEU, P. “A juventude é apenas uma palavra”. In: Questões de sociologia. Rio de Janeiro: Marco Zero, 1983.

BRAGANÇA, Aníbal \& ABREU, Márcia (orgs.). Impresso no Brasil. São Paulo: UNESP, 2010.

BERNARDO, G. "O conceito de literatura”. In: JOBIM, J. L. (org.). Introdução aos termos literários. Rio de Janeiro: EdUERJ, 1999.

BORELLI, S. H. S. "Campo editorial e mercado: a série Harry Potter". In: BRAGANÇA, A. \& ABREU, M. (orgs.). Impresso no Brasil. São Paulo: UNESP, 2010.

"Harry Potter: conexões midiáticas, produção e circulação, cenários urbanos e juvenis”. In: XXX Congresso de Ciências da Comunicação. Santos, 2007, p. 1-15.

CALLIGARIS, C. Adolescência. São Paulo: PubliFolha, 2000.

CARDOSO, G. Comunicação e recepção: o impacto da hipermídia no universo simbólico do leitor. PPGCOM- ECO, UFRJ, 2002. Tese de Doutorado. (Mimeo)

CHARTIER, R. A aventura do livro - do leitor ao navegador. São Paulo: UNESP, 1998. 
COELHO, Maria Claudia. O valor das intenções. Rio de Janeiro: FGV, 2006.

DARNTON, Robert. O beijo de Lamourette. São Paulo: Cia das Letras, 1990.

ECO, U. Seis passeios pelos bosques da ficção. São Paulo: Cia das Letras, 1994.

GARCEZ, E. Leitura, escola, leitor: uma trama plural. Programa Comunicação e Semiótica. PUC-SP, 2001. Dissertação de Mestrado. (Mimeo)

HALEWEL, Laurence. O livro no Brasil. SP: Edusp, 1985.

ISER, W. “A interação do texto com o leitor”. In: COSTA LIMA (org.). A literatura e o leitor. São Paulo: Paz e Terra, 2001.

JACKS, N. (coord.). Meios e audiências. Porto Alegre: Sulina, 2008.

\& ESCOSTEGUY, Ana Carolina de. "Recepção: uma discussão conceitual”. In: CAPARELLI, S \& SODRÉ, M. \& SQUIRRA, S. (orgs.). A comunicação revisitada. Porto Alegre: Sulina, 2005.

JAUSS, H. R. “A estética da recepção: colocações gerais”. In: COSTA LIMA (org.). A literatura e o leitor. São Paulo: Paz e Terra, 2001.

LEAL, O. F. A leitura social da novela das oito. Petrópolis: Vozes, 1986.

. "Etnografia de audiência: uma discussão metodológica". In: SOUZA, M.

W. (org.). Sujeito, o lado oculto do receptor. São Paulo: Brasiliense, 2002.

MANGUEL, A. Uma história da leitura. São Paulo: Companhia das Letras, 1997.

MARTÍN-BARBERO, J.; REY, G. Os exercícios de ver: hegemonia audiovisual e eficácia televisiva. SP: Senc, 2001.

MAUSS, Marcel. "Ensaio sobre a dádiva”. In: Sociologia e antropologia. São Paulo: EPU, 1974.

MICELI, S. A noite da madrinha. São Paulo: Perspectiva, 1972.

MILANESI, Luis Augusto. O paraíso via Embratel. São Paulo: Summus Editorial, 1977.

PETIT, M. Os jovens e a leitura. São Paulo. Editora 34, 2008.

PROENÇA, Domício. A linguagem literária. São Paulo: Ática, 2007.

REIMÃO, S. Mercado editorial brasileiro 1960-1990. São Paulo: Com Arte/FAPESP, 1996. 
ROMANCINI, R. Apropriações de Paulo Coelho por usuários de uma biblioteca pública. Ciência da Comunicação. USP, 2002. Dissertação de Mestrado. (Mimeo)

SILVA, C. E. Lins da. Muito além do Jardim Botânico. São Paulo: Summus, 1985.

SODRÉ, M. Best-seller: a literatura de mercado. São Paulo: Ática, 1988.

SPITULNIK, D. "Anthropology and mass media". In: Annual Review of Anthropology, $n^{\circ}$ 22, 1993, p. 293-314.

VASCONCELOS, M. Recepção e transgressão: o público de Augusto dos Anjos. Comunicação e Semiótica, PUC-SP, 2002. Tese de Doutorado. (Mimeo). 